\title{
Polyphenols isolated from Broussonetia kazinoki prevent cytokine-induced $\beta$-cell damage and the development of type 1 diabetes
}

\author{
Ui-Jin Bae ${ }^{1,4}$, Hyun-Young Jang ${ }^{1,4}$, Jung Min Lim² ${ }^{2}$ Li Hua ${ }^{3}$, Jae-Ha Ryu ${ }^{3}$ and Byung-Hyun Park ${ }^{1}$
}

The axis of nuclear factor кB (NF-kB)-inducible NO synthase (iNOS)-nitric oxide plays a key role in cytokine- and streptozotocinmediated pancreatic $\beta$-cell damage. In this study, we investigated the effects of kazinol $C$ and isokazinol $D$ isolated from Broussonetia kazinoki on the $\beta$-cell viability and function. RINm5F cells and primary islets were used for in vitro and ex vivo cytokine toxicity experiments, respectively. For type 1 diabetes induction, mice were injected with multiple low-dose streptozotocin (MLDS). Cytokine-induced toxicity was completely abolished in both RINm5F cells and islets that were pretreated with either kazinol C or isokazinol D. Both kazinols inhibited the NF-kB signaling pathway, thereby inhibiting cytokine-mediated iNOS induction, nitric oxide production, apoptotic cell death and defects in insulin secretion. Moreover, the occurrence of diabetes in MLDS-treated mice was efficiently attenuated in kazinol-pretreated mice. Immunohistochemical analysis revealed that the numbers of terminal deoxynucleotidyl transferase dUTP nick end labeling-positive apoptotic cells and nuclear p65positive cells were significantly decreased in kazinol-pretreated mice. Our results suggest that kazinol $C$ and isokazinol $D$ block the NF-кB pathway, thus reducing the extent of $\beta$-cell damage. Therefore, kazinol $C$ and isokazinol $D$ may have therapeutic value in delaying pancreatic $\beta$-cell damage in type 1 diabetes.

Experimental \& Molecular Medicine (2015) 47, e160; doi:10.1038/emm.2015.16; published online 24 April 2015

\section{INTRODUCTION}

Type 1 diabetes is a $\mathrm{T}$ cell-mediated disease that ultimately destroys the capacity of the body to produce and secrete insulin. ${ }^{1}$ Immune cell infiltration and the subsequent apoptotic destruction of pancreatic $\beta$-cells, also known as insulitis, are major hallmarks of this disease. ${ }^{2}$ In the early stages of disease, infiltrated inflammatory cells release cytokine such as interleukin-1 $\beta$ (IL-1 $\beta$ ), tumor necrosis factor- $\alpha$ and interferon- $\gamma$ $($ IFN- $\gamma)$. IL- $1 \beta$, either alone or in combination with tumor necrosis factor- $\alpha$ or IFN- $\gamma$, activates nuclear factor $\kappa \mathrm{B}$ (NF- $\mathrm{\kappa B}$ ) pathway, which in turn upregulates inducible nitric oxide synthase (iNOS) expression, leading to the production of nitric oxide (NO) in pancreatic islets. ${ }^{3}$

Administration of multiple low-dose streptozotocin (MLDS) to mice destroys pancreatic $\beta$-cells through a mechanism similar to that of cytokine-mediated damage. Moreover,
MLDS-induced $\beta$-cell dysfunction and destruction has been shown to be mediated by NO. ${ }^{4}$ Interestingly, mice harboring a mutation in either NF- $\mathrm{KB}$ or iNOS are resistant to MLDSinduced diabetes. ${ }^{5,6}$

Plant-derived polyphenols such as quercetin, ${ }^{7}$ genistein, ${ }^{8}$ resveratrol, ${ }^{9}$ sulfuretin ${ }^{10}$ and sulforaphane ${ }^{11}$ have been shown to protect islets against cytokine and/or streptozotocin. Plants of genus Broussonetia share polyphenols as major constituents, which were reported to exert anti-diabetic activity through the inhibition of protein tyrosine phosphatase $1 \mathrm{~B}^{12}$ and $\alpha$-glucosidase. ${ }^{13}$ We recently isolated a series of alkylated (dimethylallylated or prenylated) kazinols, which belong to the 1,3-diphenylpropane family, from the medicinal plant Broussonetia kazinoki. ${ }^{14}$ Kazinol $\mathrm{U}$, which has one prenyl group, protected $\beta$-cells against cytokine-mediated damage by suppressing the NF- $\mathrm{KB}$ pathway. ${ }^{15}$ In this study, we tested the

\footnotetext{
${ }^{1}$ Department of Biochemistry, Chonbuk National University Medical School, Jeonju, Jeonbuk, Republic of Korea; ${ }^{2}$ Department of Anatomy, Chonbuk National University Medical School, Jeonju, Jeonbuk, Republic of Korea and ${ }^{3}$ Research Center for Cell Fate Control and College of Pharmacy, Sookmyung Women's University, Seoul, Republic of Korea

${ }^{4}$ These authors contributed equally to this study.

Correspondence: Professor J-H Ryu, Research Center for Cell Fate Control and College of Pharmacy, Sookmyung Women's University, 52 Hyochangwon-Gil, Yongsan-Ku, Seoul 140-742, Republic of Korea.

E-mail: ryuha@sookmyung.ac.kr

or Professor B-H Park, Department of Biochemistry, Chonbuk National University Medical School, 567 Baekje-daero, Deokjin-gu, Jeonju, Jeonbuk 561-756, Republic of Korea.

E-mail: bhpark@jbnu.ac.kr
}

Received 11 November 2014; revised 4 January 2015; accepted 12 January 2015 
anti-diabetic efficacies of kazinol $\mathrm{C}$ and isokazinol $\mathrm{D}$, each of which has three alkyl groups in the phenyl moiety. Specifically, we exposed RINm5F insulinoma cells and isolated islets to cytokine, and then evaluated the protective effects of kazinol $\mathrm{C}$ and isokazinol D on signaling pathways that lead to apoptosis and $\beta$-cell dysfunction. We further investigated the abilities of intraperitoneally-administered kazinol $\mathrm{C}$ and isokazinol $\mathrm{D}$ to suppress type 1 diabetes and preserve functional $\beta$-cell mass in MLDS-treated mice.

\section{MATERIALS AND METHODS}

\section{Cell culture and reagents}

The RINm5F rat pancreatic $\beta$-cell line was purchased from the American Type Culture Collection (ATCC, Manassas, VA, USA). Cells were maintained at $37^{\circ} \mathrm{C}$ in a humidified $5 \% \mathrm{CO}_{2}$ atmosphere and cultured in RPMI 1640 medium (Gibco, Grand Island, NY, USA) supplemented with $10 \%$ fetal bovine serum, $2 \mathrm{~mm}$ glutamine, 100 units $\mathrm{ml}^{-1}$ penicillin, $100 \mu \mathrm{g} \mathrm{ml}^{-1}$ streptomycin and $2.5 \mu \mathrm{g} \mathrm{ml}^{-1}$ amphotericin B. IL- $1 \beta$ and IFN- $\gamma$ were obtained from R\&D Systems (Minneapolis, MN, USA). All other reagents were from Sigma-Aldrich (St Louis, MO, USA), unless otherwise noted.

\section{Preparation of kazinol C and isokazinol D}

Air-dried B. kazinoki root bark $(0.6 \mathrm{~kg})$ was extracted for $24 \mathrm{~h}$ at room temperature in 21 of ethanol. The resultant extract $(51 \mathrm{~g})$ was dissolved in water and successively partitioned with $n$-hexane, ethyl acetate, chloroform and butanol. The ethyl acetate fraction $(31 \mathrm{~g})$ was subjected to silica gel column chromatography and eluted with an $n$ hexane:acetone gradient system $(20: 1 \rightarrow 1: 10)$, thereby yielding 11 fractions. Fraction 5 was further separated by silica gel chromatography with an $n$-hexane:ethyl acetate gradient system $(20: 1 \rightarrow 1: 3)$ to yield isokazinol D $(70 \mathrm{mg})$. Fraction 7 was also subjected to silica gel column chromatography and eluted with a chloroform:methanol gradient system $(100: 1 \rightarrow 11: 1)$. The resultant eluate was further purified on an reverse phase C18 (RP-C18) column (GL Sciences Inc., Tokyo, Japan) via a gradient elution of $\mathrm{MeOH}(30 \% \rightarrow 100 \%)$, thus yielding kazinol C (260 mg).

\section{High-performance liquid chromatography analyses of kazinol $\mathrm{C}$ and isokazinol $\mathrm{D}$}

The purities of the kazinol C and isokazinol D were evaluated by highperformance liquid chromatography using the Waters 1525 system (Milford, MA, USA). A reverse-phase column (ODS-2, $150 \times 4.6 \mathrm{~mm}$ inner diameter, GL Sciences Inc.) was eluted with $80 \%$ methanol, and the resultant eluates were monitored with an ultraviolet detector at $280 \mathrm{~nm}$. Purities were calculated based on the relative peak areas on the high-performance liquid chromatography.

\section{Chemical structures of kazinol C and isokazinol D}

The molecular formula of the two kazinols was deduced as $\mathrm{C}_{30} \mathrm{H}_{40} \mathrm{O}_{4}$ by using high-resolution mass spectral data. The two kazinols also showed a typical ${ }^{1} \mathrm{H}-\mathrm{NMR}$ (proton nuclear magnetic resonance) pattern of prenylated 1,3-diphenylpropane derivatives. The NMR data indicated that kazinol $\mathrm{C}$ has two 3,3-dimethylallyl and one 1,1dimethylallyl groups. By using the heteronuclear multiple bond correlation (HMBC) correlations between the ipso carbons and protons of the respective allyl groups, the locations of the allyl groups were determined to be $\mathrm{C}-5^{\prime}$ and $\mathrm{C}-6^{\prime}$ on ring $\mathrm{A}$ and $\mathrm{C}-5^{\prime}$ on ring $\mathrm{B}$. Isokazinol $\mathrm{D}$ was also analyzed to have one 1,2-dimethylallyl group at
C-5' on ring A and one 3,3-dimethylally group at C-6' on ring B. The formation of the 2,2-dimethyldihydropyran ring was confirmed by the presence of two methylene protons $(\delta$ 1.7-1.9 and 2.5-2.7), two methyl protons $(\delta 1.33)$ and one oxygenated carbon (C-9" at $\delta 74.0)$

\section{MTT assay for cell viability}

The viability of RINm5F cells was determined by analyzing the reduction of 3-(4,5-dimethylthiazol-2-yl)-2,5-diphenyltetrazolium bromide (MTT) to formazan. ${ }^{16}$

\section{Measurement of nitric oxide}

Biologically-produced NO is rapidly oxidized to nitrite and nitrate in aqueous solutions. Thus, the production of $\mathrm{NO}$ was assessed by measuring the nitrite concentrations of cell culture supernatants via a colorimetric assay. ${ }^{16}$

\section{Electrophoretic mobility shift assay}

Nuclear extracts prepared from either RINm5F cells or islets were treated with a proteinase inhibitor cocktail (Calbiochem, San Diego, CA, USA) to inhibit endogenous protease activity. A synthetic oligonucleotide containing the $\kappa$-chain binding site ( $5^{\prime}$-CCGG TTAACAGAGGGGGCTTTCCGAG-3') was used as a probe in a gel retardation assay. The two complementary strands were then annealed and labeled with $\alpha{ }^{-}{ }^{32} \mathrm{PdCTP}$. Labeled oligonucleotides (10 000 counts per minute), $10 \mu \mathrm{g}$ nuclear extracts and binding buffer $(10 \mathrm{~mm}$ Tris- $\mathrm{HCl}(\mathrm{pH} 7.6), 500 \mathrm{~mm} \mathrm{KCl}, 10 \mathrm{~mm}$ ethylenediaminetetraacetic acid, 50\% glycerol, $100 \mathrm{ng}$ poly ( $\mathrm{dI} \cdot \mathrm{dC})$ and $1 \mathrm{~mm}$ dithiothreitol) were then incubated for $30 \mathrm{~min}$ at room temperature in a final volume of $20 \mu \mathrm{l}$. Next, the reaction mixtures were analyzed by electrophoresis on $4 \%$ polyacrylamide gels in $0.5 \times$ Tris-borate buffer. After drying the gels, radioactive bands were visualized by autoradiography. The specificity of the DNA-protein interaction for NF- $\kappa \mathrm{B}$ was confirmed via competition assays using a 50-fold excess of unlabeled oligonucleotide.

\section{Western blot analysis}

RINm5F cells $\left(5 \times 10^{6}\right)$ or 30 islets were homogenized in $100-\mu l$ icecold lysis buffer (20 mm 4-(2-hydroxyethyl)-1-piperazineethanesulfonic acid (HEPES, pH 7.2), 1\% Triton X-100, 10\% glycerol, $1 \mathrm{~mm}$ phenylmethanesulfonylfluoride, $10 \mu \mathrm{g} \mathrm{ml}^{-1}$ leupeptin and $10 \mu \mathrm{g} \mathrm{ml}^{-1}$ aprotinin). The resultant protein extracts were quantitated, and proteins $(20 \mu \mathrm{g})$ were resolved by sodium dodecyl sulfate-polyacrylamide gel electrophoresis and then transferred to nitrocellulose membranes. Membranes were probed with primary antibodies (1 $\mu \mathrm{g} \mathrm{ml}^{-1}$ ) against $\mathrm{p} 50, \mathrm{p} 65$, inhibitor of $\kappa \mathrm{B} \alpha(\mathrm{I} \kappa \mathrm{B} \alpha)$, iNOS, proliferating cell nuclear antigen and $\beta$-actin (all from Santa Cruz Biotechnology, Dallas, TX, USA), and cleaved caspase-3, Bcl-2 and Bax (Cell Signaling Technology, Beverly, MA, USA). Horseradish peroxidaseconjugated IgG (Zymed, South San Francisco, CA, USA) was used as a secondary antibody.

\section{RNA isolation and real-time RT-PCR}

RNA was isolated from RINm5F cells or islets using Trizol (Invitrogen, Carlsbad, CA, USA), and then precipitated with isopropanol and dissolved in diethylpyrocarbonate-treated distilled water. Total RNA $(2 \mu \mathrm{g})$ was treated with RNase-free DNase (Invitrogen), and firststrand cDNA was generated using a random hexamer primer with a first-strand cDNA synthesis kit (Applied Biosystems, Foster City, CA, USA). Specific primers for iNOS were designed using primer express software (Applied Biosystems). Primers used were: iNOS (accession 
no. NM_012611): 5'-TGTGCTAATGCGGAAGGTCAT-3' (forward) and 5'-CGACTTTCCTGTCTCAGTAGCAAA-3' (reverse). Control $18 \mathrm{~S}$ ribosomal RNA was purchased from Applied Biosystems and used as an internal control. Real-time RT-PCR reactions consisted of $10 \mathrm{ng}$ reverse-transcribed total RNA, $167 \mathrm{nM}$ forward and reverse primers, and $2 \times$ PCR master mix in a final volume of $10 \mu$ l. Reactions were carried out in 384-well plates using an ABI Prism 7900HT sequence detection system (Applied Biosystems).

\section{Islet isolation and determination of islet viability}

Pancreatic islets were isolated from male C57BL/6 mice by using the collagenase digestion method. Islet viability was evaluated as previously described. ${ }^{17}$ Briefly, islets were incubated with cytokine and fixed overnight in a solution of $6.5 \%$ glutaraldehyde. Islet viability was determined by hematoxylin and eosin (H\&E) staining and subsequent labeling with anti-insulin antibodies (Santa Cruz Biotechnology). Apoptosis was detected using an ApoPercentage apoptosis assay kit (Biocolor, Newtownabbey, Ireland). Apoptotic islets, which are stained red after the selective uptake of ApoPercentage dye (Biocolor), were detected using an inverted light microscope (Axiovert 40 CFL microscope, Carl Zeiss, Oberkochen, Germany). ${ }^{18}$

\section{Glucose-stimulated insulin secretion assay}

Islets were cultured for $24 \mathrm{~h}$ with cytokine and then washed three times in Krebs-Ringer bicarbonate buffer (25 mM HEPES ( $\mathrm{pH} 7.4$ ), $115 \mathrm{~mm} \mathrm{NaCl}, 24 \mathrm{~mm} \mathrm{NaHCO}, 5 \mathrm{~mm} \mathrm{KCl}, 1 \mathrm{~mm} \mathrm{MgCl}_{2}, 2.5 \mathrm{~mm}$ $\mathrm{CaCl}_{2}$ and $0.1 \%$ bovine serum albumin) containing $3 \mathrm{~mm}$-glucose. Insulin secretion assays were performed with either 2.8 or $16.7 \mathrm{~mm}$ D-glucose.

\section{Induction of diabetes by injection of MLDS}

Pathogen-free male C57BL/6 mice, each weighing 25-30g, were purchased from Orient Bio (Seoul, Korea). Mice were housed in a laminar flow cabinet with a 12-h light/dark cycle, and maintained on standard laboratory chow ad libitum. To induce diabetes, mice were injected via the tail vein with streptozotocin (Sigma-Aldrich) dissolved in $0.1 \mathrm{M}$ sodium citrate buffer $(\mathrm{pH} 4.0)$, at a dose of $40 \mathrm{mg} \mathrm{kg}^{-1}$ per day, for five consecutive days. Mice were divided into the following groups: (1) nontreated control, (2) MLDS, (3) kazinol C+MLDS and (4) isokazinol D+MLDS. Control animals received citrate buffer alone. Groups 3 and 4 received daily intraperitoneal injections of either kazinol $\mathrm{C}$ or isokazinol $\mathrm{D}$ for 3 days before the administration of streptozotocin. The day on which streptozotocin was first administered was defined as day 1 . At day 5 , mice were killed by decapitation without anesthesia, and trunk blood was collected in prechilled tubes containing $1 \mathrm{mg} \mathrm{ml}^{-1}$ ethylenediaminetetraacetic acid. Plasma glucose levels were assayed using the glucose oxidase method (Sigma-Aldrich), whereas plasma insulin levels were measured using a rat/mouse insulin enzyme-linked immunosorbent assay kit (Linco Research, St Charles, MO, USA). All animal experiments were performed in accordance with the Guide for the Care and Use of Laboratory Animals, published by the US National Institutes of Health (NIH Publication No. 85-23, revised 2011). The current study protocol was also approved by the Institutional Animal Care and Use Committee of Chonbuk National University (Permit No. CBU 2014-00061).

\section{Histological assessment}

Mice were killed under nonfasting conditions. Pancreatic specimens were immediately fixed in 10\% formalin solution, embedded in paraffin and cut into $5 \mu \mathrm{m}$ sections. Specimens were stained with
H\&E to identify morphological changes. For immunohistochemical analysis, tissue sections were treated with a microwave antigen retrieval procedure using $10 \mathrm{~mm}$ sodium citrate buffer. After blocking endogenous peroxidase activity, the sections were incubated with DAKO protein block serum-free (DAKO, Carpinteria, CA, USA) to block nonspecific staining. Sections were then incubated with anti-insulin antibodies (Santa Cruz Biotechnology) or anti-p65 antibodies (Abcam Biotech, Cambridge, MA, USA). Peroxidase activity was detected with 3-amino-9-ethylcarbazole.

Terminal deoxynucleotidyl transferase dUTP nick end labeling (TUNEL) staining was performed using a commercial kit (R\&D Systems). Five to six random sections per slide were investigated to determine the percentage of apoptotic islets.

\section{Statistical analysis}

Statistical analysis was performed using analysis of variance and Duncan's tests. Differences with a $P$ value $<0.05$ were considered statistically significant.

\section{RESULTS}

Purification and structural analyses of kazinol $\mathrm{C}$ and isokazinol D from B. kazinoki

The purities of $B$. kazinoki-derived preparations of kazinol C and isokazinol D were assessed by high-performance liquid chromatography (Figure 1a). The clean peaks at retention times of 15.2 and $16.25 \mathrm{~min}$ in the high-performance liquid chromatography indicate pure preparations of kazinol $\mathrm{C}$ and isokazinol $\mathrm{D}$, respectively. The purities were determined to be
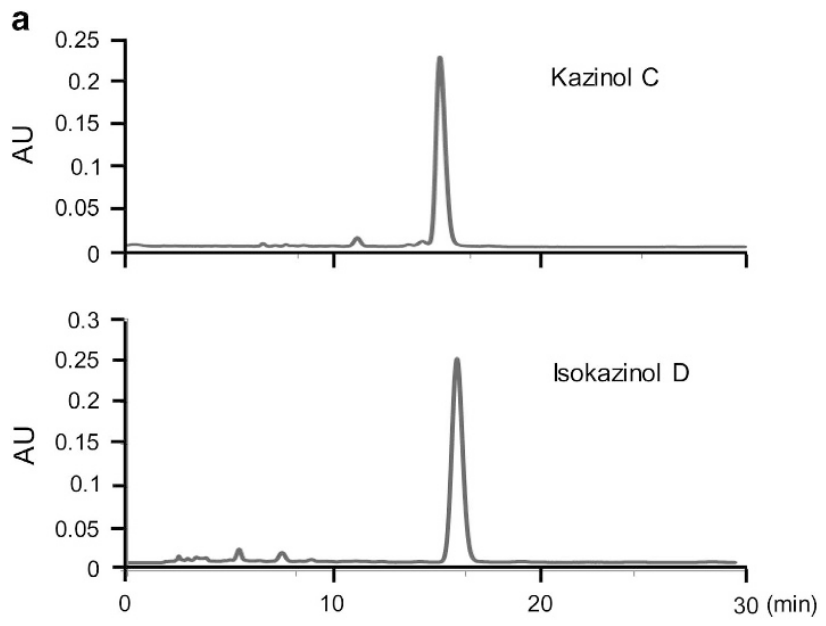

b<smiles>C=CC(C)(C)c1cc(CCCc2cc(O)c(O)c(CC=C(C)C)c2CC=C(C)C)c(O)cc1O</smiles>
Kazinol C

Isokazinol D

Figure 1 High-performance liquid chromatography (a) and chemical structures (b) of kazinol C and isokazinol D. 
a

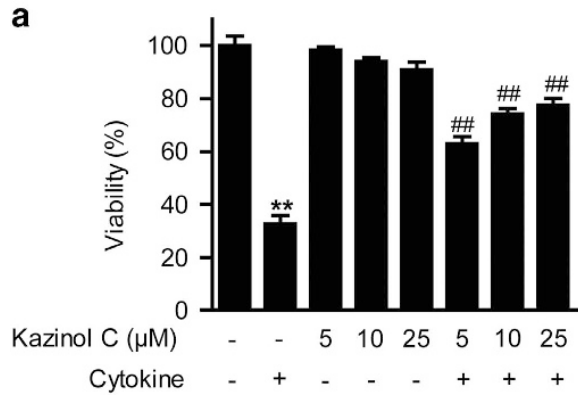

b

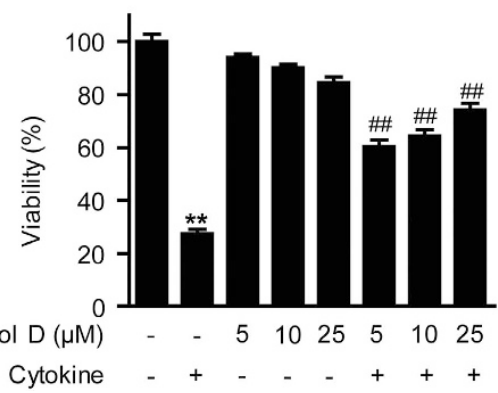

Figure 2 Prevention of cytokine-induced cell death in RINm5F cells. Cells were pretreated with the indicated concentrations of kazinol C (a) or isokazinol $\mathrm{D}(\mathbf{b})$ for $3 \mathrm{~h}$, and then IL-1 $\beta\left(1 \mathrm{U} \mathrm{ml}^{-1}\right)$ and IFN- $\gamma\left(100 \mathrm{U} \mathrm{ml}^{-1}\right)$ were added and cells were incubated for an additional $48 \mathrm{~h}$. Cell viability was determined using the MTT assay. Each value is the mean \pm s.e.m. of three independent experiments $(n=9)$. ${ }^{* *} P<0.01$ versus vehicle-treated control; $\# \#<0.01$ versus cytokine-treated cells.

$>95 \%$ (kazinol C) and >93\% (isokazinol D). Kazinol C and isokazinol $\mathrm{D}$ were elucidated by spectroscopic analysis to be 1,3-diphenyl propane derivatives, structures which are common among phenolic compounds isolated from B. kazinoki (Figure 1b).

Effects of kazinol C and isokazinol D on cytokine-induced cell death and NO production in RINm5F cells

To determine whether kazinol $\mathrm{C}$ and isokazinol $\mathrm{D}$ exert protective effects on $\beta$-cells, we first investigated whether kazinol C and isokazinol D protect RINm5F cells against cytokine toxicity. Treatment with two cytokines, IL-1 $\beta$ and IFN- $\gamma$, significantly reduced cell viability to $67-72 \%$ that of control cells; however, pretreatment with either kazinol $\mathrm{C}$ or isokazinol D increased the viability of cytokine-treated RINm5F cells in a concentration-dependent manner (Figures 2a and b). Treatment with either kazinol C or isokazinol D alone had no effect on cell viability at the concentrations used in these experiments. In addition, treatment with either kazinol $\mathrm{C}$ or isokazinol D after cytokine exposure did not increase cell viability (data not shown).

Next, the production of $\mathrm{NO}$ was evaluated. At $24 \mathrm{~h}$, control and cytokine-treated RINm5F cells generated $2.37 \pm 0.49$ and $15.5 \pm 1.56 \mu \mathrm{m}$ nitrite, respectively (Figure $3 \mathrm{a}$ ). The production of $\mathrm{NO}$ was almost completely inhibited by pretreatment with either $25 \mu \mathrm{m}$ kazinol $\mathrm{C}$ or isokazinol $\mathrm{D}$.

We next investigated the effects of kazinol $\mathrm{C}$ and isokazinol D on cytokine-mediated expression of iNOS mRNA and protein by real-time RT-PCR and western blotting, respectively. Cytokine treatment increased the levels of iNOS mRNA and protein (Figure 3a). However, pretreatment with either kazinol $\mathrm{C}$ or isokazinol D before cytokine treatment resulted in concentration-dependent decreases in mRNA and protein levels.

Effects of kazinol C and isokazinol D on cytokine-mediated activation of NF- $\kappa$ B in RINm5F cells

$\mathrm{NF}-\mathrm{\kappa B}$ has been implicated in the transcriptional regulation of cytokine-induced iNOS expression. ${ }^{3}$ Therefore, we examined the effects of kazinol C and isokazinol D on the cytokinestimulated translocation of NF-KB from the cytosol to the nucleus in RINm5F cells. Nuclear extracts were prepared $1 \mathrm{~h}$ after cytokine treatment and used to analyze NF-кB-DNAbinding activity and cytoplasmic IкB $\alpha$ degradation. The binding of the p65 subunit to an NF- $\mathrm{kB}$ consensus sequence was increased in cytokine-treated RINm5F cells; moreover, the nuclear levels of the p65 and p50 subunits were increased (Figure $3 \mathrm{~b}$ ). In contrast, pretreatment with either kazinol C or isokazinol D markedly suppressed the nuclear translocation and DNA-binding ability of NF- $\mathrm{KB}$, suggesting that kazinol $\mathrm{C}$ and isokazinol D inhibit iNOS expression by suppressing NF-kBmediated transcriptional activation. In addition, cytokine-treated RINm5F cells showed decreased levels of cytosolic IкB $\alpha$ due to I $\mathrm{B} \alpha$ degradation; this decrease was markedly suppressed by pretreatment with either kazinol C or isokazinol D (Figure 3b).

Effects of kazinol C and isokazinol D on cytokine-induced apoptosis and glucose-stimulated insulin secretion in mouse islets

We further assayed the protective effects of kazinol $\mathrm{C}$ and isokazinol D using pancreatic islets isolated from mice. Islets were exposed to IL- $1 \beta$ and IFN- $\gamma$ for $48 \mathrm{~h}$, fixed, and then either stained with $\mathrm{H} \& \mathrm{E}$ or immunostained with anti-insulin antibodies. Similar to the results observed in RINm5F cells, cytokine treatment resulted in islet damage and weak insulin immunoreactivity (Figure 4a). However, pretreatment with either $25 \mu \mathrm{m}$ kazinol $\mathrm{C}$ or isokazinol D prevented these cytokine-induced changes. Pretreated islets with kazinols exhibited a similar morphology to control islets, as assessed by both H\&E and immunohistochemical staining. Both control islets and kazinol-pretreated islets had well-defined margins and a round shape, in addition to exhibiting strong insulin immunoreactivity in their $\beta$-cells (Figure $4 a$ ).

We next evaluated the extent of apoptosis in the islets using an ApoPercentage apoptosis assay kit (Biocolor; Figures 4a and b). Almost four times more apoptosis was observed in the cytokine-treated islets compared with the vehicle-treated islets $(83.3 \pm 4.8 \%$ versus $20.6 \pm 3.6 \%, P<0.01)$. However, significantly less apoptosis was observed in the $25-\mu \mathrm{M}$ kazinol C-pretreated islets $(30.0 \pm 4.8 \%, P<0.01)$ and in the $25-\mu \mathrm{M}$ isokazinol D-pretreated islets $(24.2 \pm 3.4 \%, P<0.01)$ than in the cytokine-treated islets. Pretreatment with either $10 \mu \mathrm{M}$ kazinol C or isokazinol D also partially blocked cytokine- 
a
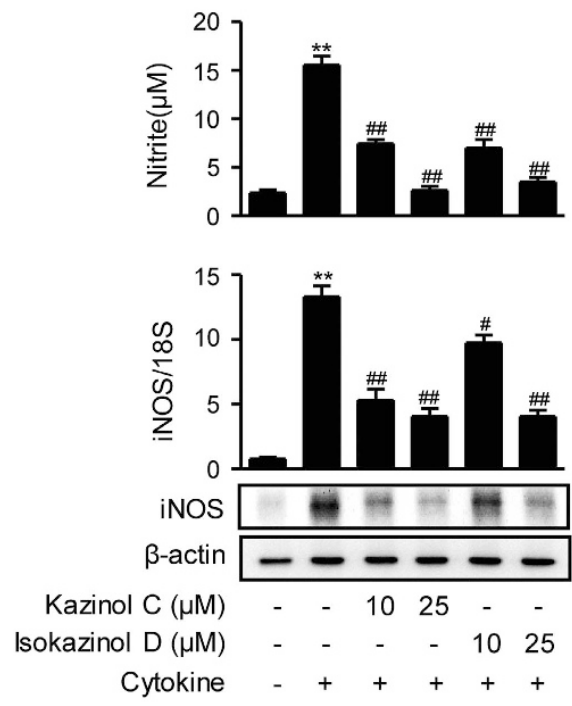

b

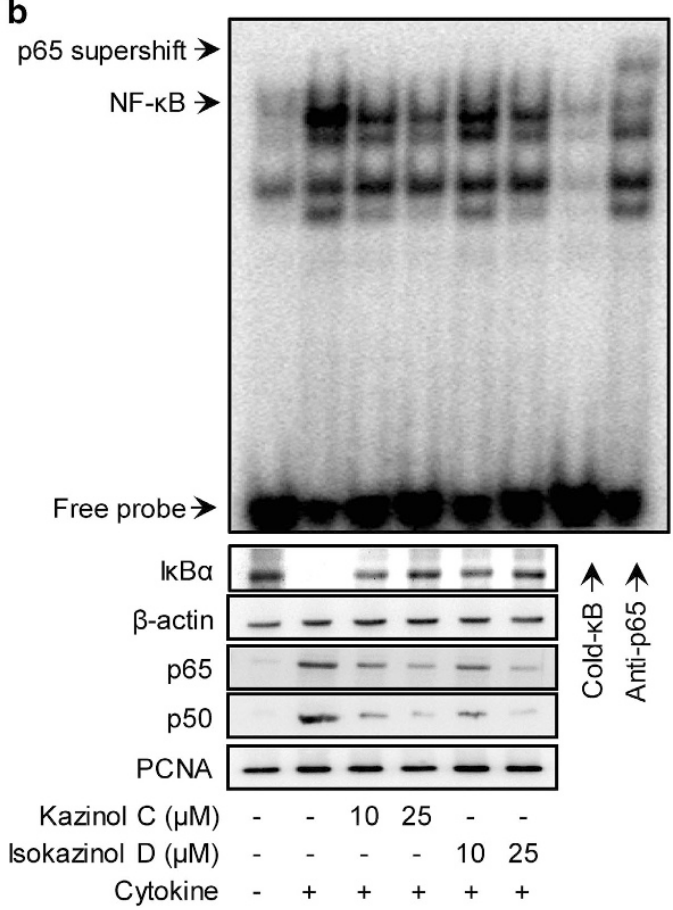

Figure 3 Prevention of cytokine-induced NF-kB activation in RINm5F cells. (a) RINm5F cells were pretreated with the indicated concentrations of kazinol C or isokazinol D for $3 \mathrm{~h}$, and followed by IL-1 $\beta$ and IFN- $\gamma$ treatment. Following $24 \mathrm{~h}$ of incubation, the concentration of nitrite and the expression of iNOS mRNA and protein were determined. Each value is the mean \pm s.e.m. of three independent experiments $(n=9)$. ${ }^{* *} P<0.01$ versus vehicle-treated control; ${ }^{\# \#} P<0.01$ versus cytokine-treated cells. (b) After 30 min, NF-KB DNA binding was analyzed by electrophoretic mobility shift assay, and the nuclear translocation of the p65 and p50 subunits and the level of cytoplasmic $1 \kappa B \alpha$ were determined by western blotting. $\beta$-actin and proliferating cell nuclear antigen (PCNA) were used as loading controls for cytosolic and nuclear proteins, respectively.

induced apoptosis. Consistently, increased levels of the proapoptotic proteins Bax and cleaved caspase- 3 , in addition to the decreased level of the anti-apoptotic protein Bcl-2, were observed in cytokine-treated islets. These effects were reversed in kazinol C- or isokazinol D-pretreated islets (Figure 4c).

To investigate the functional effects of kazinol $\mathrm{C}$ and isokazinol $\mathrm{D}$, we pretreated islets with these compounds and evaluated their effects on cytokine-induced impairment of insulin secretion. Basal- and glucose-stimulated insulin secretion levels were measured after exposure to cytokine for $24 \mathrm{~h}$. As shown in Figure 4d, control islets secreted $18.7 \pm 1.4$ $\mathrm{ng} \mathrm{mg} \mathrm{g}^{-1}$ protein per hour of insulin after glucose stimulation, whereas cytokine-treated islets secreted $6.2 \pm 2.1 \mathrm{ng} \mathrm{mg}^{-1}$ protein per hour under the same conditions $(P<0.01)$. However, following pretreatment with $25 \mu \mathrm{m}$ of either kazinol $\mathrm{C}$ or isokazinol D, cytokine-treated islets secreted insulin upon glucose stimulation at a rate similar to that of control islets. Basal insulin release among the groups was similar.

Incubation of the islets with cytokine for $24 \mathrm{~h}$ resulted in a fivefold increase in NO production (Figure 5a). Real-time RT-PCR and western blotting revealed that iNOS mRNA and protein levels, respectively, were markedly increased by cytokine treatment (Figure 5a). Consistent with the results obtained in RINm5F cells, pretreatment with $25 \mu \mathrm{m}$ of either kazinol C or isokazinol D reduced the cytokine-mediated upregulation of NO production, and also reduced the level of iNOS expression to similar levels of control islets. In addition, cytokine treatment increased NF- $\mathrm{KB}$ DNA binding, nuclear translocation of $\mathrm{NF}-\kappa \mathrm{B}$ subunits and cytoplasmic I $\mathrm{KB} \alpha$ degradation; however, pretreatment with either kazinol C or isokazinol D markedly reduced these effects in islets (Figure $5 b$ ).

\section{Effects of kazinol C and isokazinol D on MLDS-mediated induction of diabetes}

Our in vitro and ex vivo results indicated that kazinol $\mathrm{C}$ and isokazinol D protect $\beta$-cells from cytokine-mediated damage, thus increasing islet viability. To examine whether this $\beta$-cell protection prevents the development of diabetes, mice were given kazinols daily with intraperitoneal injections of either kazinol C or isokazinol D for 3 days before the administration of streptozotocin. Administration of MLDS resulted in hyperglycemia, with a mean blood glucose level of $401 \pm 34 \mathrm{mg} \mathrm{dl}^{-1}$ on day 5 (Figure 6a). In contrast, mice that had been pretreated with kazinol C $\left(10 \mathrm{mg} \mathrm{kg}^{-1}\right)$ or isokazinol $\mathrm{D}\left(10 \mathrm{mg} \mathrm{kg}^{-1}\right)$ were fully resistant to the development of diabetes. Treatment with kazinol $\mathrm{C}$ or isokazinol $\mathrm{D}$ alone did not affect blood glucose concentration (data not shown). In addition, on day 5 , the plasma insulin level was decreased by $40 \%$ in the MLDStreated mice compared with the control mice (from $0.53 \pm 0.13$ to $0.13 \pm 0.02 \mathrm{ng} \mathrm{ml}^{-1}$ ). However, the severity of hypoinsulinemia was attenuated in mice that had been pretreated with either kazinol C or isokazinol D. These results indicate that 
a

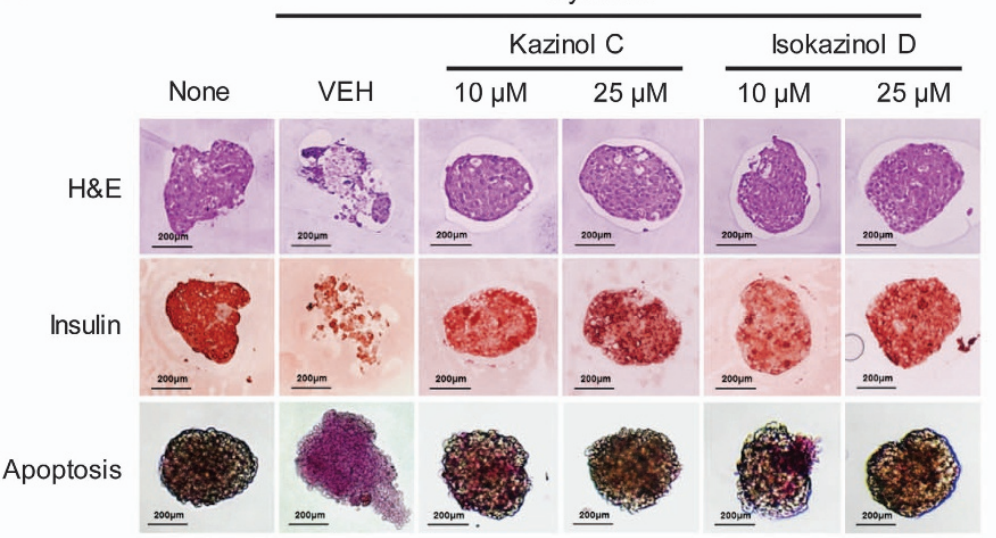

C

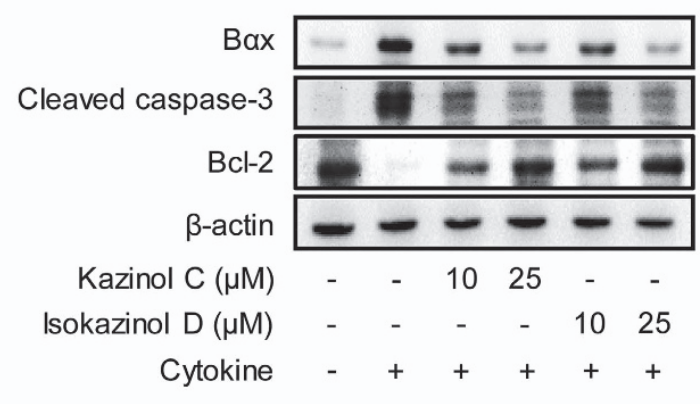

b

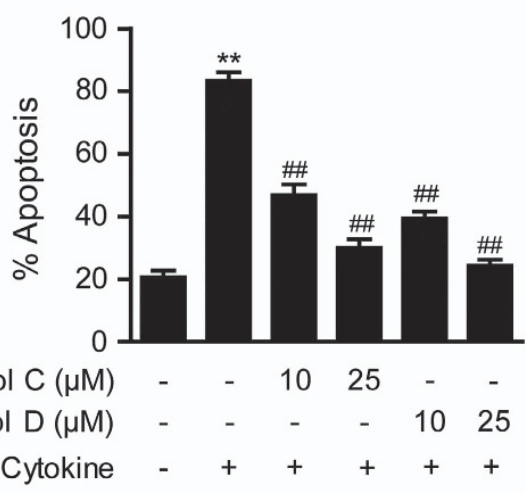

d

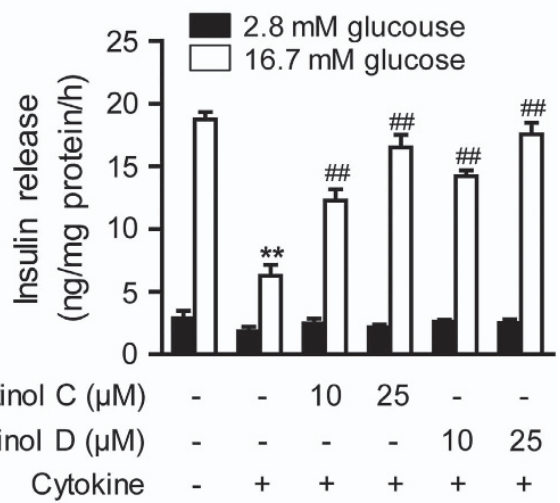

Figure 4 Prevention of cytokine-induced apoptosis in isolated islets. (a) Mice islets were treated with IL-1 $\beta$ and IFN- $\gamma$, either with or without a 3-h pretreatment with the indicated concentrations of kazinol C or isokazinol D. Following a 48-h incubation, islets were either stained with H\&E or labeled with anti-insulin antibodies, and then examined by microscopy. Apoptosis was evaluated using the APOPercentage apoptosis assay kit. Apoptotic islets appear bright pink. (b) The numbers of apoptotic islets were expressed as percentages of the total numbers of islets. (c) Islet extracts were prepared $24 \mathrm{~h}$ after cytokine treatment, and the levels of apoptosis-related proteins were examined by western blotting. (d) Glucose-stimulated insulin secretion was quantified by enzyme-linked immunosorbent assay and normalized to the total protein content. The results of triplicate samples are expressed as means \pm s.e.m. $(n=9)$. ${ }^{* *} P<0.01$ versus vehicle-treated control; ${ }^{\#} P<0.01$ versus cytokine-treated islets.

both kazinol $\mathrm{C}$ and isokazinol $\mathrm{D}$ exert protective effects against MLDS-induced diabetes. Histological examination of the islets from MLDS-treated mice revealed degenerative and destructive changes, as well as weak insulin immunoreactivity (Figure 6b). In contrast, islets from mice that had been pretreated with either kazinol C or isokazinol D exhibited a round, nearly normal shape with a well-defined margin, in addition to strong insulin immunoreactivity (Figure 6b).

Since both kazinol C and isokazinol D protected islets against cytokine-mediated apoptotic injury and preserved their ability to secrete insulin, we next examined whether kazinol C and isokazinol D protected pancreatic islets against apoptosis. Fewer apoptotic islets were observed in kazinol C- and isokazinol D-pretreated mice compared with nontreated mice, as assessed by TUNEL staining (Figure 6b). The mean number of TUNEL-positive cells in MLDS-treated mice was almost seven times higher than that of control mice $(8.4 \pm 2.7 \%$ versus $58.0 \pm 8.8 \%, P<0.01)$. The numbers of TUNEL-positive islets were also significantly reduced in kazinol C-pretreated (17.6 \pm
4.7\%, $P<0.01)$ and isokazinol D-pretreated $(19.8 \pm 7.9 \%$, $P<0.01)$ mice compared with MLDS-treated mice (Figure $6 \mathrm{c}$ ).

To elucidate the anti-diabetogenic mechanism(s) of kazinol $\mathrm{C}$ and isokazinol D, we examined their effects on streptozotocin-induced NF- $\kappa \mathrm{B}$ activation by immunohistochemical staining. Administration of MLDS to mice resulted in the nuclear translocation of the p65 NF- $\kappa \mathrm{B}$ subunit (Figure 6d). In contrast, increased nuclear translocation was not observed in pancreatic sections from kazinol C- or isokazinol D-pretreated mice. Taken together, these results indicate that both kazinol $\mathrm{C}$ and isokazinol D inhibit NF- $\kappa \mathrm{B}$ activation and prevent the development of type 1 diabetes in mice.

\section{DISCUSSION}

Multiple lines of evidence suggest that NF- $\kappa \mathrm{B}$-dependent NO production is a critical factor in the destruction and dysfunction of $\beta$-cells. ${ }^{4-6}$ In $\beta$-cells, NF- $\mathrm{BB}$ activation can be triggered by cytokine or diabetogenic drugs such as streptozotocin and alloxan. ${ }^{3,6,19}$ Therefore, reducing NF- $\mathrm{BB}$ activity is one of the 
a

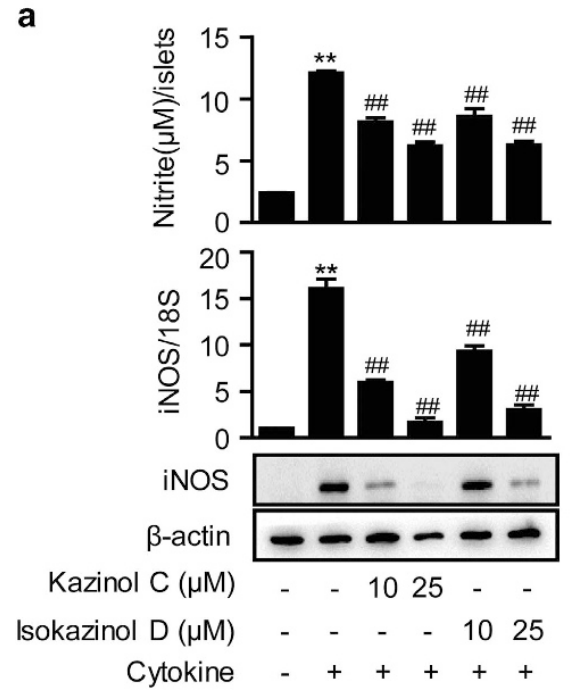

b

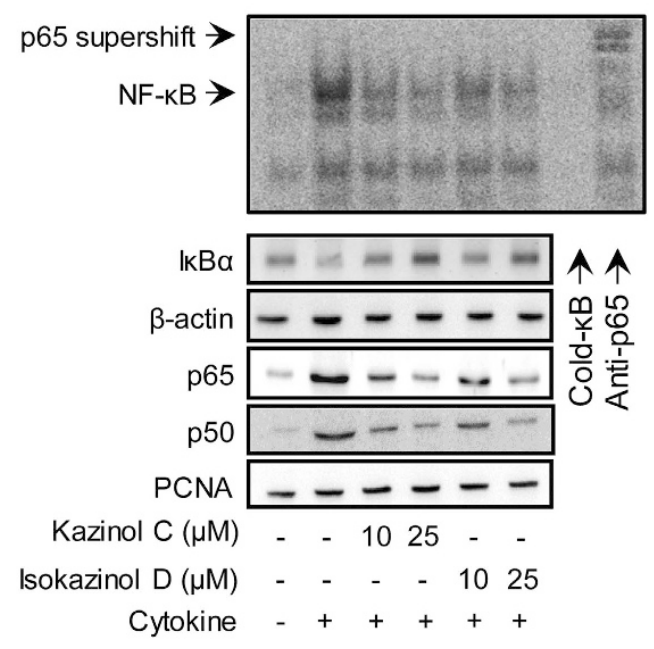

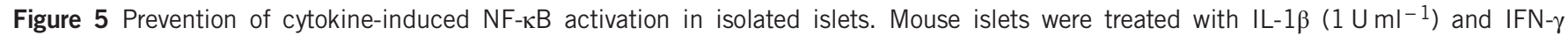
$\left(100 \mathrm{U} \mathrm{ml}^{-1}\right.$ ), either with or without a 3-h pretreatment with the indicated concentration of kazinol C or isokazinol D. (a) The concentration of nitrite and the expression of iNOS mRNA and protein were determined after $24 \mathrm{~h}$. (b) The extents of NF-kB DNA binding, $I_{\kappa} B \alpha$ degradation and nuclear translocation of $p 65$ and $p 50$ were determined $1 \mathrm{~h}$ later. The results of triplicate samples are expressed as means \pm s.e.m. $(n=9) .{ }^{* *} P<0.01$ versus vehicle-treated control; ${ }^{\#} P<0.01$ versus cytokine-treated islets.

strategies for overcoming $\beta$-cell failure. In traditional Chinese medicine, B. kazinoki has been used as a suppressant for edema; moreover, several polyphenols have been reported to show cytotoxic, anti-oxidative, anti-inflammatory and tyrosinase-inhibitory activities. ${ }^{20,21}$ With the aim of identifying novel NF-KB inhibitors, we previously isolated a series of kazinols from B. kazinoki, and evaluated their abilities to inhibit NO production in lipopolysaccharide-stimulated RAW264.7 macrophages (ATCC). ${ }^{22}$ Among the kazinols tested, kazinol C and isokazinol D exhibited the most promising NF- $\kappa B$ suppressive activity and were thus selected for further studies of their anti-diabetic efficacy. Here, we showed that kazinol C and isokazinol D are indeed able to protect pancreatic $\beta$-cells from cytokine-induced apoptosis and also to preserve the ability of islets to secrete insulin in response to glucose stimulation. Consistent with these in vitro and ex vivo effects on $\beta$-cell survival and function, in vivo studies also demonstrated the protective effects of kazinol C and isokazinol D against the development of MLDS-induced diabetes.

We observed that the optimal concentrations of kazinol C and isokazinol D for protecting $\beta$-cells from cytokine-induced cell death was $25 \mu \mathrm{M}$. This concentration is far lower than that of kazinol U, of which $60 \mu \mathrm{m}$ is required to suppress NF- $\kappa B$ activation and protect $\beta$-cells against cytokine-mediated damage. ${ }^{15}$ Kazinol C and isokazinol D both share the same 1,3-diphenylpropane backbone, but they have different substitution patterns in their phenyl rings. Kazinol $\mathrm{C}$ has three dimethylallyl groups, while isokazinol D has two dimethylallyl groups and one dimethyldihydropyran ring system, which was formed by the ring closure to a dimethylallyl group. In contrast, kazinol $\mathrm{U}$ has only one dimethylallyl group. The number of hydrophobic allyl groups may affect cell permeability, which might explain the weaker protective activity of kazinol $U$ against cytokine-mediated damage in $\beta$-cells. One previous study demonstrated that the stem bark powder of B. kazinoki exhibited anti-hyperglycemic activity in an animal model of diabetes. However, only the crude powder of this plant was used in that study, and the protective mechanism was not investigated. ${ }^{23}$

We first investigated whether kazinol $\mathrm{C}$ and isokazinol D suppress NF-KB activity in pancreatic $\beta$-cells, and found that both kazinols suppressed the cytokine-mediated increases of iNOS mRNA and protein levels in both RINm5F cells and islets. Consistent with these observations, cytokine-stimulated NO production was significantly reduced by pretreatment with kazinol C or isokazinol D. Moreover, western blotting and electrophoretic mobility shift assay data showed that both kazinols suppressed NF- $\mathrm{KB}$ activity. Since NF- $\mathrm{KB}$ is known to regulate iNOS expression and, consequently, NO production, ${ }^{3}$ these results indicate that kazinol $\mathrm{C}$ and isokazinol $\mathrm{D}$ both efficiently suppress NF- $\mathrm{KB}$ activity in pancreatic $\beta$-cells.

As a key regulator of inflammatory and cell survival responses, NF- $\mathrm{KB}$ participates in both the generation of proinflammatory mediators and the anti-apoptotic pathway. The balance between these two pathways determines the fate of $\beta$-cells that are exposed to cytokine. These contradictory roles of NF- $\kappa B$ help explain several conflicting reports that NF- $\kappa B$ inactivation either protects against cytokine toxicity ${ }^{24,25}$ or aggravates such injury, ${ }^{26,27}$ although the underlying reasons for these discrepant results are not entirely clear. Part of the explanation might be that NF- $\mathrm{KB}$ is differentially activated under different conditions, such as in rodent versus human islets, ${ }^{28,29}$ immortalized $\beta$-cells versus primary $\beta$-cells, ${ }^{25}$ different cytokine mixtures and varying incubation times, ${ }^{25,27,30}$ and different animal models of diabetes induction. ${ }^{24,27}$ In our experimental conditions, kazinol C and isokazinol D decreased 
a
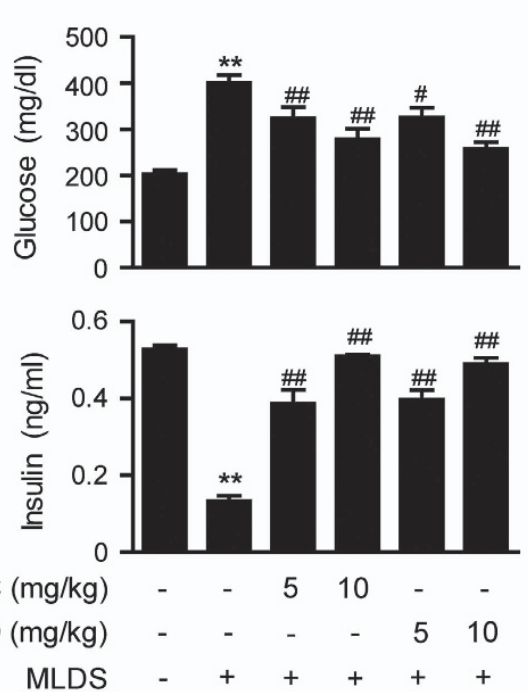

C

$\begin{array}{rrrrrrr}\text { Kazinol C (mg/kg) } & - & - & 5 & 10 & - & - \\ \text { Isokazinol D (mg/kg) } & - & - & - & - & 5 & 10 \\ \text { MLDS } & - & + & + & + & + & +\end{array}$

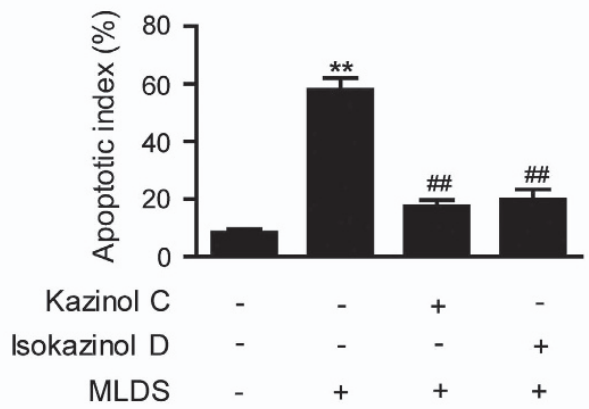

b

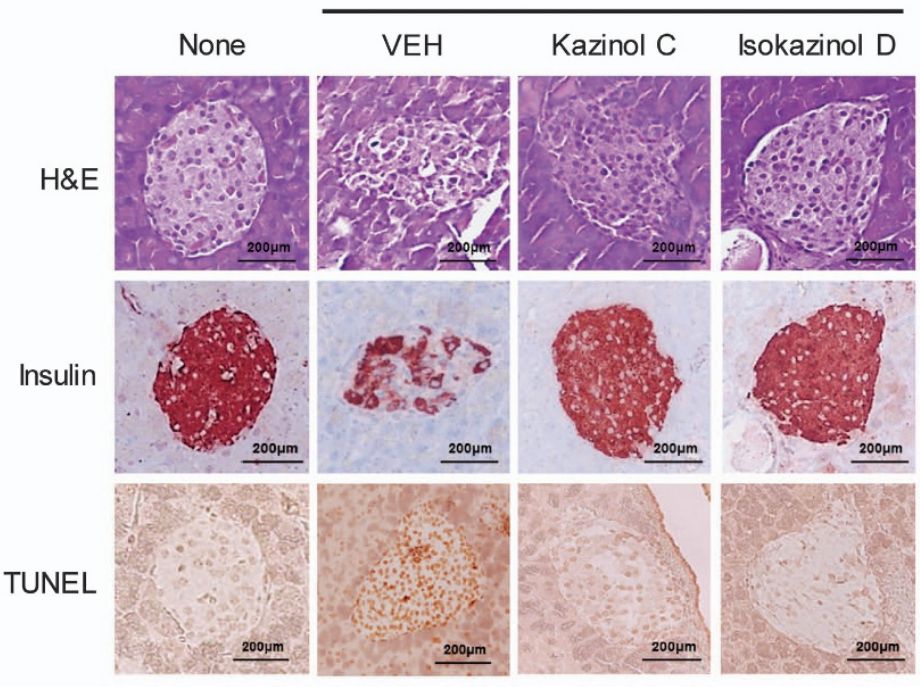

d

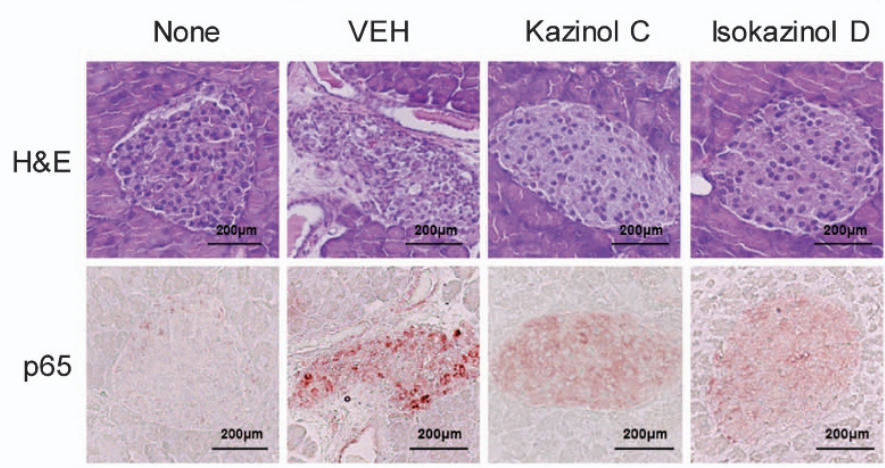

Figure 6 Protection of islets from MLDS-induced destruction. Type 1 diabetes was induced as described in the Materials and Methods section. (a) Levels of glucose and insulin were determined. Results are expressed as means \pm s.e.m. $(n=9)$. ${ }^{* *} P<0.01$ versus untreated control; ${ }^{\#} P<0.05$ and ${ }^{\#} P<0.01$ versus MLDS mice. (b) Pancreases were obtained from normal control mice and from mice injected with MLDS, kazinol C and MLDS, or isokazinol D and MLDS. The cellular morphologies of islets and the adjoining exocrine regions were examined after counterstaining with H\&E. Islets were either immunolabeled with anti-insulin antibodies or TUNEL stained, and then examined by microscopy. (c) The numbers of apoptotic islets were determined by counting and expressed as percentages of the total numbers of islets. (d) Nuclear translocation of the NF-kB p65 subunit was confirmed by immunohistochemical staining. Similar results were obtained from three independent experiments.

the levels of the proapoptotic proteins Bax and cleaved caspase3 , whereas the level of the anti-apoptotic protein Bcl-2 was increased in cytokine-treated islets. In addition, the number of apoptotic islets in the ex vivo diabetic condition was significantly reduced by kazinol C or isokazinol D treatment, suggesting that NF-kB suppression by kazinol $\mathrm{C}$ and isokazinol D shifted the balance toward suppression of the apoptotic pathway.

This evidence for the anti-apoptotic and anti-diabetic activities of kazinol $\mathrm{C}$ and isokazinol $\mathrm{D}$ was strengthened by the finding that intraperitoneal administration of either kazinol $\mathrm{C}$ or isokazinol D resulted in a remarkable resistance to the development of diabetes in MLDS-treated mice. The importance of the NF- $\mathrm{KB}-\mathrm{iNOS}-\mathrm{NO}$ cascade in the development of type 1 diabetes has previously been reported in a mouse MLDS model. ${ }^{9,31}$ In streptozotocin-treated mice, increased expression of iNOS and the concomitant overproduction of $\mathrm{NO}$ in $\beta$-cells are observed at a very early stage. In this situation, NO may react with superoxide anion to generate a strong oxidizer peroxynitrite, and thus leading to aggressive oxidative and nitrosative stress. ${ }^{32}$ However, a recent study by Broniowska et al. ${ }^{33}$ showed that pancreatic $\beta$-cells do not generate peroxynitrite in response to cytokine, suggesting that $\mathrm{NO}$ is not the likely mediator of the toxic effects of cytokine. In the present study, we found that MLDS treatment induced insulin deficiency and hyperglycemia in mice, which is a typical phenotype of type 1 diabetes. Importantly, immunohistochemical staining showed that kazinol $\mathrm{C}$ and isokazinol $\mathrm{D}$ both prevented the MLDS-mediated nuclear translocation of NF- $\mathrm{KB}$ subunits, suggesting that the in vivo anti-diabetic potentials of kazinol $\mathrm{C}$ and isokazinol $\mathrm{D}$ are related to the suppression of $\mathrm{NF}-\kappa \mathrm{B}$. Consistent with these data, treatment with kazinol C or 
isokazinol D markedly reduced the numbers of TUNELpositive apoptotic islet cells. These results are consistent with our ex vivo results and demonstrate the importance of NF- $\mathrm{\kappa B}$ suppression in preserving pancreatic $\beta$-cell viability.

It could be argued that the protection failure of kazinols against the post cytokine injury limits their therapeutic potential. Although type 1 diabetes is usually diagnosed in its final stage, the disease course in humans is a longer process. Therefore, kazinols can be used to delay the disease progression. Kazinols can also be used in transplantation to enhance survival of donor islets and preserve functional islet mass. This hypothesis is supported by the observation that conditional and specific inhibition of NF- $\mathrm{KB}$ improves transplantation outcomes. ${ }^{34}$ In summary, our results indicate that kazinol C and isokazinol D both inhibit cytokine- and streptozotocininduced $\beta$-cell damage in vitro, ex vivo and in an in vivo model of diabetes. The primary mechanism underlying these effects is the inhibition of iNOS protein expression, which may be mediated at the transcriptional level through the inhibition of NF- $\kappa \mathrm{B}$ activation.

\section{CONFLICT OF INTEREST}

The authors declare no conflict of interest.

\section{ACKNOWLEDGEMENTS}

This work was supported by the Bio \& Medical Technology Development Program (No. NRF-2012M3A9B2027975) and the Medical Research Center Program (No. 2008-0062279 and 20110030074) through the National Research Foundation, which is funded by the Korean government (MSIP).

1 American Diabetes Association, Diagnosis and classification of diabetes mellitus. Diabetes Care 2014; 37(Suppl 1): S81-S90.

2 Cnop M, Welsh N, Jonas JC, Jorns A, Lenzen S, Eizirik DL. Mechanisms of pancreatic $\beta$-cell death in type 1 and type 2 diabetes: many differences, few similarities. Diabetes 2005; 54(Suppl 2): S97-S107.

3 Eizirik DL, Colli ML, Ortis F. The role of inflammation in insulitis and $\beta$-cell loss in type 1 diabetes. Nat Rev Endocrinol 2009; 5: 219-226.

4 Lukic ML, Stosic-Grujicic S, Shahin A. Effector mechanisms in low-dose streptozotocin-induced diabetes. Dev Immunol 1998; 6 : 119-128.

5 Flodstrom M, Tyrberg B, Eizirik DL, Sandler S. Reduced sensitivity of inducible nitric oxide synthase-deficient mice to multiple low-dose streptozotocin-induced diabetes. Diabetes 1999; 48: 706-713.

6 Mabley JG, Hasko G, Liaudet L, Soriano FG, Southan GJ, Salzman AL et al. NFkB1 (p50)-deficient mice are not susceptible to multiple low-dose streptozotocin-induced diabetes. J Endocrinol 2002; 173 : 457-464.

7 Kim EK, Kwon KB, Song MY, Han MJ, Lee JH, Lee YR et al. Flavonoids protect against cytokine-induced pancreatic $\beta$-cell damage through suppression of nuclear factor $\kappa B$ activation. Pancreas 2007; 35: e1-e9.

8 Kim EK, Kwon KB, Song MY, Seo SW, Park SJ, Ka SO et al. Genistein protects pancreatic $\beta$ cells against cytokine-mediated toxicity. Mol Cell Endocrinol 2007; 278: 18-28.

9 Lee SM, Yang H, Tartar DM, Gao B, Luo X, Ye SQ et al. Prevention and treatment of diabetes with resveratrol in a non-obese mouse model of type 1 diabetes. Diabetologia 2011; 54: 1136-1146.

10 Song MY, Jeong GS, Kwon KB, Ka SO, Jang HY, Park JW et al. Sulfuretin protects against cytokine-induced $\beta$-cell damage and prevents streptozotocin-induced diabetes. Exp Mol Med 2010; 42 628-638.
11 Song MY, Kim EK, Moon WS, Park JW, Kim HJ, So HS et al. Sulforaphane protects against cytokine- and streptozotocin-induced $\beta$-cell damage by suppressing the NF-kB pathway. Toxicol Appl Pharmacol 2009; 235: 57-67.

12 Chen RM, Hu LH, An TY, Li J, Shen Q. Natural PTP1B inhibitors from Broussonetia papyrifera. Bioorg Med Chem Lett 2002; 12: 3387-3390.

13 Ryu HW, Lee BW, Curtis-Long MJ, Jung S, Ryu YB, Lee WS et al. Polyphenols from Broussonetia papyrifera displaying potent $\alpha$-glucosidase inhibition. J Agric Food Chem 2010; 58: 202-208.

$14 \mathrm{Kim}$ AY, Lee CG, Lee da Y, Li H, Jeon R, Ryu JH et al. Enhanced antioxidant effect of prenylated polyphenols as Fyn inhibitor. Free Radic Biol Med 2012; 53: 1198-1208.

15 Bae UJ, Lee da Y, Song MY, Lee SM, Park JW, Ryu JH et al. A prenylated flavan from Broussonetia kazinoki prevents cytokine-induced $\beta$-cell death through suppression of nuclear factor-kB activity. Biol Pharm Bull 2011; 34: 1026-1031.

16 Bae UJ, Song MY, Jang HY, Gim HJ, Ryu JH, Lee SM et al. The efficacy of SPAO355 in protecting $\beta$ cells in isolated pancreatic islets and in a murine experimental model of type 1 diabetes. Exp Mol Med 2013; 45: e51.

17 Song MY, Bae UJ, Jang KY, Park BH. Transplantation of betacellulintransduced islets improves glucose intolerance in diabetic mice. Exp Mol Med 2014; 46: e98.

18 Su D, Zhang N, He J, Qu S, Slusher S, Bottino R et al. Angiopoietin-1 production in islets improves islet engraftment and protects islets from cytokine-induced apoptosis. Diabetes 2007; 56: 2274-2283.

19 Ho E, Chen G, Bray TM. Supplementation of N-acetylcysteine inhibits $\mathrm{NFKB}$ activation and protects against alloxan-induced diabetes in CD-1 mice. FASEB J 1999; 13: 1845-1854.

20 Baek YS, Ryu YB, Curtis-Long MJ, Ha TJ, Rengasamy R, Yang MS et al. Tyrosinase inhibitory effects of 1,3-diphenylpropanes from Broussonetia kazinoki. Bioorg Med Chem 2009; 17: 35-41.

21 Zhang PC, Wang S, Wu Y, Chen RY, Yu DQ. Five new diprenylated flavonols from the leaves of Broussonetia kazinoki. J Nat Prod 2001; 64: 1206-1209.

22 Ryu JH, Ahn H, Jin Lee $\mathrm{H}$. Inhibition of nitric oxide production on LPS-activated macrophages by kazinol B from Broussonetia kazinoki. Fitoterapia 2003; 74: 350-354

23 Cha JY, Kim YT, Kim HS, Cho YS. Antihyperglycemic effect of stem bark powder from paper mulberry (Broussonetia kazinoki Sieb.) in type 2 diabetic Otsuka Long-Evans Tokushima fatty rats. J Med Food 2008; 11: 499-505.

24 Eldor R, Yeffet A, Baum K, Doviner V, Amar D, Ben-Neriah Y et al. Conditional and specific NF-kB blockade protects pancreatic $\beta$ cells from diabetogenic agents. Proc Natl Acad Sci USA 2006; 103: 5072-5077.

25 Ortis F, Pirot P, Naamane N, Kreins AY, Rasschaert J, Moore F et al. Induction of nuclear factor- $\mathrm{\kappa} B$ and its downstream genes by TNF- $\alpha$ and IL-1 $\beta$ has a pro-apoptotic role in pancreatic $\beta$ cells. Diabetologia 2008; 51 : 1213-1225.

26 Hagerkvist R, Sandler S, Mokhtari D, Welsh N. Amelioration of diabetes by imatinib mesylate (Gleevec): role of $\beta$-cell NF-kB activation and antiapoptotic preconditioning. FASEB J 2007; 21: 618-628.

27 Kim S, Millet I, Kim HS, Kim JY, Han MS, Lee MK et al. NF-kB prevents $\beta$ cell death and autoimmune diabetes in NOD mice. Proc Natl Acad Sci USA 2007; 104: 1913-1918.

28 Cardozo AK, Proost P, Gysemans C, Chen MC, Mathieu C, Eizirik DL. IL-1 $\beta$ and IFN- $\gamma$ induce the expression of diverse chemokines and IL-15 in human and rat pancreatic islet cells, and in islets from pre-diabetic NOD mice. Diabetologia 2003; 46: 255-266.

29 Mokhtari D, Barbu A, Mehmeti I, Vercamer C, Welsh N. Overexpression of the nuclear factor-kB subunit c-Rel protects against human islet cell death in vitro. Am J Physiol Endocrinol Metab 2009; 297: E1067-E1077.

30 Heimberg H, Heremans Y, Jobin C, Leemans R, Cardozo AK, Darville M et al. Inhibition of cytokine-induced NF-kB activation by adenovirusmediated expression of a NF-kB super-repressor prevents $\beta$-cell apoptosis. Diabetes 2001; 50: 2219-2224.

31 Lewis EC, Blaabjerg L, Storling J, Ronn SG, Mascagni P, Dinarello CA et al. The oral histone deacetylase inhibitor ITF2357 reduces cytokines and protects islet $\beta$ cells in vivo and in vitro. Mol Med 2011; 17: 369-377. 
32 Szabo C, Ischiropoulos H, Radi R. Peroxynitrite: biochemistry, pathophysiology and development of therapeutics. Nat Rev Drug Discov 2007; 6: $662-680$

33 Broniowska KA, Mathews CE, Corbett JA. Do $\beta$-cells generate peroxynitrite in response to cytokine treatment? J Biol Chem 2013; 288: 36567-36578.

34 Rink JS, Chen X, Zhang X, Kaufman DB. Conditional and specific inhibition of NF-KB in mouse pancreatic $\beta$ cells prevents cytokineinduced deleterious effects and improves islet survival posttransplant. Surgery 2012; 151: 330-339. (c) (1) $(\Theta)$ This work is licensed under a Creative Commons Attribution-NonCommercial-NoDerivs 4.0 International License. The images or other third party material in this article are included in the article's Creative Commons license, unless indicated otherwise in the credit line; if the material is not included under the Creative Commons license, users will need to obtain permission from the license holder to reproduce the material. To view a copy of this license, visit http://creativecommons.org/licenses/by-nc-nd/4.0/ 